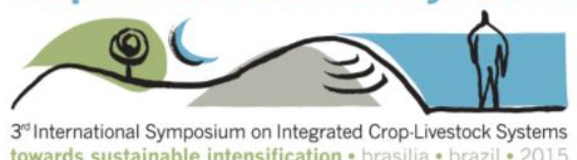

\title{
Spatial variability of soil fertility in an integrated crop livestock forest system
}

Alberto C. de Campos BERNARDI ${ }^{1 *}$; José Ricardo M. PEZZOPANE ${ }^{1 *}$; Sérgio Novita ESTEVES ${ }^{1}$; André de Faria Pedroso $^{1}$; Teresa Cristina ALVES ${ }^{1}$; Patrícia P. A. OLIVEIRA ${ }^{1}$

${ }^{1}$ Embrapa Cattle Southeast, São Carlos, SP, Brazil;

E-mail address of presenting author*: alberto.bernardi@embrapa.br

Introduction The knowledge of spatial variability soil properties is useful in the rational use of inputs, as in the site specific application of lime and fertilizer. The objective of this research was to evaluate the changes and the spatial variability of soil fertility parameters in an integrated croplivestock-forest system (ICLFS).

Material and Methods The 6-ha field experiment was carried out at Embrapa Cattle Southeast in São Carlos, SP, Brazil (21 ${ }^{\circ} 57^{\prime} \mathrm{S}, 4^{\circ} 50^{\prime} \mathrm{W}, 860 \mathrm{~m}$ alt) during the growing season of 2013/2014. The ICLFS is planted with Eucalyptus urograndis (GG100) planted in single rows with $15 \mathrm{~m}$-distance and $2 \mathrm{~m}$ between plants. Pasture is Urochloa brizantha cv. Piatã. Annually $1 / 3$ of area is renewed with the corn sown together with the Piatã grass. Soil fertility parameters $\left(\mathrm{P}, \mathrm{K}^{+}\right.$, cation exchange capacity - CEC, basis saturation-V\% and soil organic matter - SOM) were evaluated at 1.5; 3.0; and $7.5 \mathrm{~m}$ distance from the trees and 0-20 cm depth, before and after annual crop corn growth.

\section{Results and Conclusions}

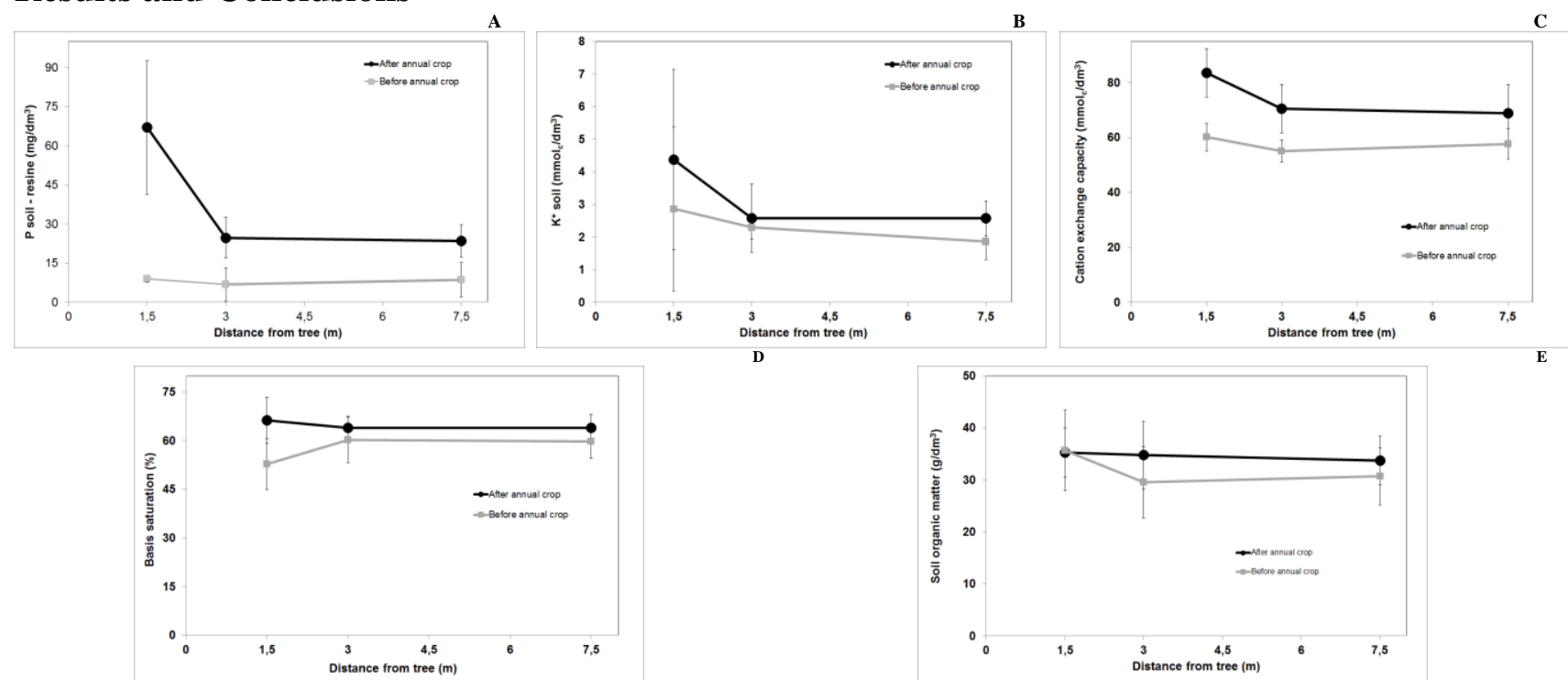

Figure1. P (A), $\mathrm{K}^{+}(\mathrm{B}), \mathrm{CEC}(\mathrm{C}), \mathrm{V} \%$ (D) and SOM (E) in an ICLFS, as a function of distance form trees and after and before the growth of annual crop (corn). São Carlos, SP, Brazil- 2013/2014 growing season.

Soil P; $\mathrm{K}^{+}$and $\mathrm{CEC}$ values increased with liming and fertilization applied to the annual crop at the renewing of the pasture. There are no differences $\mathrm{V} \%$ and SOM values. As close as the trees $(1.5 \mathrm{~m})$ there were higher values of $\mathrm{P}, \mathrm{K}$ and $\mathrm{CEC}$ comparing to the further point $(7,5 \mathrm{~m})$. These differences probably were due the lower biomass production of corn and pasture plants close to trees, which received nutrients, however they did not absorbed it. Results showed the accumulation of nutrients close to the trees, leading a spatial variability in the system. Liming and fertilization practices of the next season should consider these differences, instead of uniform application of lime and fertilizers.

\section{Acknowledgements}

To Embrapa, International Potash Institute (IPI) and CNPq for financial support. 